\title{
Relationship between Macroeconomic Policy and Long-Run Economic Growth of Nepal
}

\section{Mohan Khanal 투}

Lecturer, NIST College, Kathmandu, Nepal

* Corresponding Author (itsmk19@gmail.com)

Received: 04 September, 2021

Revised: 14 October, 2021

Accepted: 22 November, 2021

Published: 25 December, 2021

How to cite this paper: Khanal, M, (2021). Relationship between macroeconomic policy and long run economic growth of Nepal. Quest Journal of Management and Social Sciences, 3(2), pp. 265-276.

Copyright (C) 2021 by authors and Quest Journal of Management and Social Sciences.

This work is licensed under a Creative Commons Attribution-Non Commercial-No Derivatives 4.0 International License.

https://creativecommons.org/ licenses/by-nc-nd/4.0/

\begin{abstract}
Background: The paper is an attempt to find the long-run relationship between macroeconomic variables and economic growth in Nepal. The variables in the study are run across the Cobb-Douglas production model.
\end{abstract}

Objective: This paper examines the relationship between Gross Fixed Capital Formation, Population, Trade openness, Money Supply and GDP growth economic growth in Nepal.

Method: The ARDL bound test and Error Correction model incorporated in the study to examine the long-run relationship among macroeconomic variables.

Conclusion: Based on the Bound Test of F-statistics the Cointegration Result exists among the variable and $\operatorname{ARDL}(1,1,1,1,1)$ relation is estimated.

Implications: Since the study has found the existence of a cointegration relationship on the variables of the study and the long-term relationship among economic growth is significant with GFCF. The policy should be targeted at investment growth in Nepal.

Paper Types: Research Paper

Key Words: Cointegration, Autoregressive Distributed Lag (ARDL), Vector Error Correction (VEC)

JEL Classification: E6, O11 


\section{Introduction}

Macroeconomic policy is aimed at driving the economy, thus achieving economic growth and maintaining stability. Economic growth generally referred to an increase in the output of the economy. The function of this output is its association to Investment, Labor and policy variables. Many studies have presented a linear relation of the aforementioned variables to output growth. This study tries to go further exploring the relation from the Augmented- Cobb Douglas function of output in Nepal. Thus, a functional relationship is a setup based on the previous studies of the application of Cobb Douglas relation. basic indicators of macroeconomic policy are the inflation rate, the budget surplus or deficit, and the black-market exchange premium. Since the inflation rate, due to pegged exchange rate regime with India, is highly influenced by the inflation of the Indian economy, the researcher will take broad money as the best indicator of the monetary policy. The general notion of a stable macroeconomic framework is a macroeconomic policy environment that is conducive to growth.

According to Faux (2019), "the economic policies implemented to address prevailing economic problems have differed depending on the economic circumstances". While these economic policies were implemented with the belief that good policy could be decisive for growth, the policies being promoted during the crisis and adjustment decade from 1986-1995, were inspired by the BrettonWoods institutions, with its emphasis on market-oriented economic policies, openness to foreign trade, and minimal government restrictions. Similar economic policy reform in Nepal led to liberalization of the macro-economic and financial sector that led to international trade, flourishing financial service and economic welfare of people began to widen. To achieve higher growth, gross fixed capital formation is considered as a pivotal determinant and, thus, targeted gross fixed capital formation for growth is assumed to be backed by the appropriate volume of savings. An increase in savings and the use of it in capital formation constitute one of the strategies for higher growth in Nepal (Budha, 2012).

This study is an attempt to determine the extent to which these policies affect economic growth in Nepal. This study analyses the determinants of economic growth in Nepal using the recent theory of endogenous growth spurred by the works of Romer (1986) and Lucas Jr (1988). According to this theory, economic growth can be affected by the economic policy which contrasts sharply with the Solow-Swan neoclassical model in which long-term growth depends on exogenous technical progress and, therefore, invariant to policy (Solow, 1956; Swan, 1956).

Based on the study of Easterly and Rebelo (1993), the extent to which economic policy contributes to output growth depends on country-specific features especially within the African context, where growth was found to be considerably unstable than country characteristics. Following the endogenous growth theory, we attribute long-term economic growth not only to factor accumulation also to the productivity of factors that are drawn by efficiency gains in the use of factors and technological progress. In addition to economic policy, the quality and quantity of human capital can contribute significantly to economic growth. Human capital tends to improve the quality of labor and productivity of labor, which in turn engenders economic growth. Economic policies and the quality of institutions, on the other hand, affect the efficacy of resource use; contribute to growth in total factor productivity thus contributing to sustainable growth. The rapid growth of East Asian economies since the 1960s is attributed to a combination of determinants including human and physical capital, openness to foreign trade and foreign direct investment, effective government policies that accompany technological progress and factor accumulation (World Bank, 1993). This paper, thus, examines the relationship between the economic growth, investment labor growth, money supply, trade openness variable using the ARDL approach. Moreover, with the application of error correction, it tries to have insight into the possibility of investment-led growth and growth-driven investment hypothesis in detail. 
The paper is arranged into five sections. Section 1 consists of an introduction to the subject of study; Section 2 reviews the relevant literature. Section 3 discusses model specification and methodology and Section 4 makes the empirical analysis. Finally, Section 5 concludes the study.

\section{Review of Literature}

\section{Contribution of Economic Policy to Growth}

In various works of growth theories, macroeconomic policies have been shown to have long-term growth effects. A two-factor Cobb-Douglas production function became significant. Various proportions and combinations of labor and capital are included in this function. The function developed in this proposition became the core of the models of economic growth.

The recent development of growth models has gone beyond Solow's neoclassical growth model that exhibited diminishing returns to capital and labor separately and constant returns to both factors jointly, and that left technological progress as a residual. Since Solow's model does not allow for a more in-depth analysis of the determinant. Other researchers have attempted to decompose growth into contributing factors using refined models that allowed for such factors as human capital, technological improvements embodied in the capital, multiple sectors ( Zaman \& Goschin, 2010).

The endogenous growth theory seeks to explain changes in technology by analyzing the role of investment in research, training, and education by firms as well as by government, and the role of government policies in changing incentives to promote physical and human capital (Oztürkler \& Bozgeyik, 2014)).

In a study, Dervis and Petri (1987) highlight the correlation between growth and variables related to macroeconomic management, and among regressors are inflation rate, external debt ratio and the budget surplus. The results are based on a cross-sectional study of per capita growth and standard new growth theory variables, over the period 1970-198. Easterly and Rebelo (1993) underlined growth resulting from an increase in supplies of factors and to a residual productivity category, reflecting changes in the efficiency with which factors are used. The author lays out an approach to examine the relationships between growth and macroeconomic variables, and then between the macroeconomic variables and changes in both the supplies of factors, and the residual, or productivity. Budha (2012) analyzed the ARDL model-based cointegration among domestic savings, investment and growth of Nepal. The study shows that there is evidence of cointegration between Gross Domestic Saving (GDS), Gross Fixed Capital Formation (GFCF) and Gross Domestic Product (GDP) when GDP is taken as a dependent variable. However, the finding shows a low impact of investment on growth since the longrun investment multiplier is found to be less than one.

\section{Theoretical Framework}

Most empirical studies based on the Cobb-Douglas model explain the long-term growth through two distinctive segments by the growth in factor inputs and by improvements in efficiency with which these inputs are used. The latter is called total factor productivity (TFP). Estimates of TFP lead to the identification of economic policies which affect growth. The factor inputs represent the elasticities of the increment of economic output concerning changes in the variables, and these elasticities are constant, thus indicating the shares of the production factors in the total output. Following the proposed model by Faux (2019), we estimate a function of growth rate based on Cobb-Douglas production and the logarithm form of the production function. We have,

$$
Y=F(K, L, A)
$$


where Y denotes real aggregate output or income, K represents physical capital, L is labor or number of workers and A is an overall efficiency factor that does not only include technology but also the quality of government economic policies. A constant return to scale Cobb-Douglas production yields aggregate output as:

$$
Y t=A_{t} K_{t}^{\alpha} L_{t}^{\beta} \text { with } \alpha+\beta=1
$$

The natural logarithm of equation (2) is as follows:

$$
\log Y_{t}=\log A_{t}+\alpha \log K_{t}+\beta \log L_{t}
$$

Total factor productivity (A)is assumed to grow as:

$$
A_{t}=A_{0} e^{\sum \theta X_{i t}}
$$

where $\mathrm{x}$ is a vector of growth rates for the $X i t^{1}$. Applying logarithmic transformation to equation (4) and expressing the growth rate $\mathrm{x}$ as $\Delta \log \mathrm{x}$, we get:

$$
\log A_{0}+\theta_{1} \Delta \log X_{1 t}+\theta_{2} \Delta \log X_{2 t}+\ldots \ldots+\theta_{n} \Delta \log X_{n, t}+\xi_{t}
$$

On substitution of equation (5) to (3), we get

$$
\begin{gathered}
\log Y_{t}=\log A_{0}+\alpha \log K_{t}+\theta_{1} \Delta \log X_{1 t}+\ldots \ldots \theta_{n} \Delta \log X_{n, t}+\xi_{t} \\
\log Y_{t}=\log A_{0}+\alpha \log K_{t}+\beta \log L_{t}+\gamma_{1} \log X_{1 t}+\ldots \ldots \gamma_{n} \log X_{n, t}+\xi_{t}
\end{gathered}
$$

Generally, changes in the logarithm of $\mathrm{X}\left(\Delta \log \mathrm{X}_{\mathrm{it}}{ }^{1}\right)$ are interpreted as the effects of policies and institutions on the aggregate productivity of factors. The above specification forms the basis of our empirical analysis.

\section{Research Methods}

\section{Data and Variable Definition}

Based on the framework developed for the relationship among variables to perform co-integration analysis series data from 1991-2018 has been taken. The data in the study has been drawn from the World Development Indicators (WDI) and World Bank databases.

\section{ARDL Model}

The ARDL method is utilized to establish to test whether there is any long-run association among the time series due to several reasons (Pesaran et al., 2001). First, since the sample size is very low due to the unavailability of data, the ARDL method is employed since it is the most suitable method in the small sample size providing more robust results. The small size also provides robust results given that the diagnostic tests pass all the tests (Akbota \& Baek, 2018). Secondly, the order of integration, whether $\mathrm{I}(0)$ or I(1), would not make any difference while estimating the equations under the ARDL model. However, the estimation process would crash in the presence of $\mathrm{I}(2)$ series. The ARDL $\left(\mathrm{p}, \mathrm{q}_{1}, \mathrm{q}_{2}, \mathrm{q}_{3}, \mathrm{q}_{4}\right)$ equation formulation of the equation (2) is presented as follows:

\footnotetext{
${ }^{1} 1 . \mathrm{X}_{\mathrm{it}}$ comprises variables such as broad money, fiscal balance, government expenditure as a share of GDP, current account balance and other economic and institutional variables embodied in $\mathrm{A}$.
} 


\section{Definitions of Variables}

The variables used in estimating the growth equation are defined in the table below as follows:

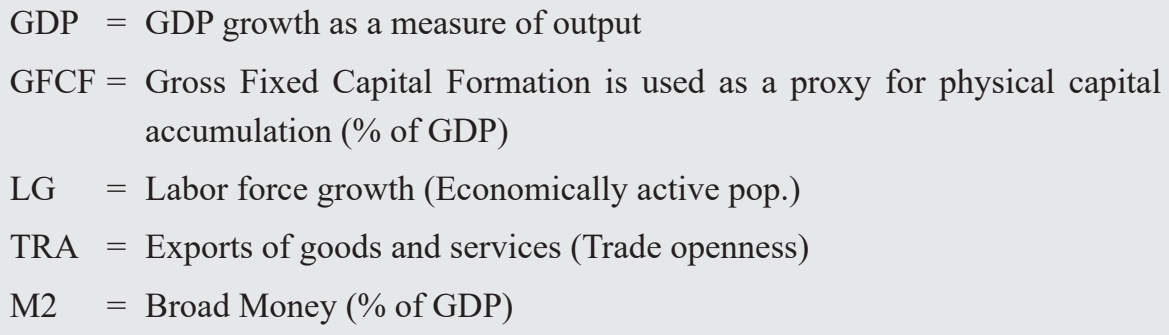

Data on Gross Domestic Product, Gross Fixed Capital Formation and Broad money has been logtransformed. Labor force growth data are rates of change in labor force participation year on year.

\section{Trend Analysis}

Trend analysis of variables in Figure 1 is the time series plot of variables of the study at a level. The GDP has increased steadily across the study period. Gross Fixed Capital formation has increased in the first decade and remained stationary till 2015 before a fall. Similarly, the broad money supply (M2) to GDP i.e., m2gdp is increasing over time. Labor variable represented through working population group (15-64) steadily over the period. Exports represented by trade openness (TRA) of Nepal i.e., found to be growing exponentially over the past years.

\section{Figure 1, Trend of Macroeconomic variables}
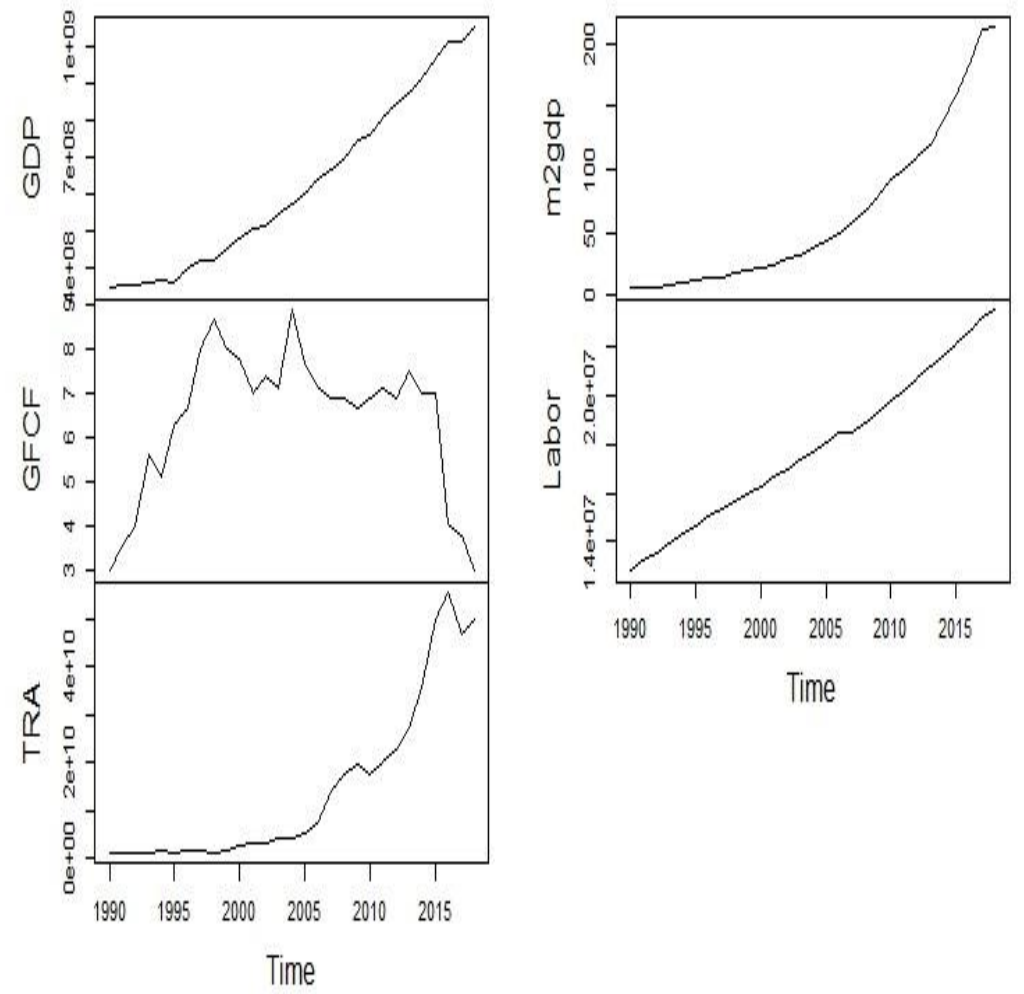


\section{Econometric Model}

\section{ARDL Cointegration Approach}

The autoregressive distributed lag (ARDL) cointegration procedure introduced by Pesaran and Shin (1999) and Pesaran, Shin, and Smith $(1997,2001)$ was used to examine the long-run relationship between the GDP growth, Gross Fixed Capital Formation, the World Development Indicators (WDI), World Bank database, Broad Money, and Trade Openness. This test has several advantages over the well-known residual-based approach proposed by Engle and Granger (1987) and the maximum likelihood-based approach proposed by Johansen and Julius (1990) and Johansen (1992). The main advantage of this test is that it can be applied irrespective of the order of integration while other cointegration techniques require all variables to be of equal degree of integration. In addition, it does not matter whether the explanatory variables are exogenous (Pesaran \& Shin, 1997). The short and long-run parameters with appropriate asymptotic inferences can be obtained by applying OLS to ARDL with an appropriate lag length. Pesaran et al. (2001) provide the two sets of critical values in which the lower critical bound assumes that all the variables in the ARDL model are I(0), and the upper critical bound assumes I(1). If the calculated F-statistics is greater than the appropriate upper bound critical values, the null hypothesis is rejected implying cointegration. If such a statistic value is below the lower bound, the null cannot be rejected, indicating any cointegration. If, however, it lies within the lower and upper bounds, the result is inconclusive. After establishing the evidence of the existence of the cointegration between variables, the lag orders of the variables are chosen by using the appropriate Akaike Information Criteria (AIC) or Schwarz Bayesian Criteria (SBC).

\section{Unit Root Test}

The stationary of the variables is determined using the testing strategies recommended by Phillips and Perron (1988). The unit root hypothesis is tested using the Augmented Dickey-Fuller (ADF) test, which is equivalent to running the following set of regressions for each of the variables.

$$
\begin{aligned}
& \Delta Y_{t}=\beta_{0}+\beta_{1}+\beta_{2} Y_{t-1}+\sum_{j=1}^{p} \beta_{j} \Delta y_{t-j}+\mu_{t} \\
& \Delta Y_{t}=\lambda \beta_{0}+\beta_{1} \cdot \pi Y_{t-1}+\sum_{I=1}^{p-1} r_{i} \Delta Y_{t-I}+B X_{t-1}+\vartheta_{t}
\end{aligned}
$$

where $\Delta \mathrm{Y}$ is the difference of $\mathrm{Y}, \mathrm{t}$ is a trend and $\mu$ is a disturbance term. The test runs the null hypothesis of unit root at $\beta_{2}=1$ using a t-test.

\section{The ARDL Model}

The investigation of the long-run relationship between GDP, GFCF, LG, TRA and M2 in a cointegration framework begins with an examination of integration properties of the data. If the variables are integrated of order one, then the determination of the cointegration rank using Johansen and Juselius (1990) maximum likelihood cointegration procedure follows. Since the dependent variable of the study is integrated at order 0, we explore the relationship using the following ARDL.

When the number of lags of $i^{\text {th }}$ independent series is shown by $p_{i}, i=1, \ldots, k$, we write the ARDL model as:

$$
Y_{t}=\mu+\sum_{i=1}^{k} \beta_{0} X_{t i}+\beta_{1} X_{(t-1) i}+\cdots+\beta_{p i} X_{(t-p) i}+\gamma_{1} Y_{(t-1)}+\cdots+\gamma_{q} Y_{(t-q)}+e_{t}
$$

where $\mu$ is the constant, $Y_{t}$ and $X_{t i}$ are respectively dependent and $i^{\text {th }}$ independent series, $p_{i}$ is the lag order of $\mathrm{i}^{\text {th }}$ independent series, $\mathrm{q}$ is the autoregressive order of the model, and et shows the innovations. 


$$
\begin{aligned}
\Delta \log G D P_{t}= & \mu_{t}+\alpha \log G D P_{t-1}+\beta \log X_{t-1}+\sum_{i=1}^{p} \gamma_{i} \Delta \log G D P_{t-i}+ \\
& \sum_{i=1}^{p} \gamma_{i} \Delta \log X_{t-i}+\xi_{t}
\end{aligned}
$$

where,

$$
X=G F C F, L G, T R A, M 2
$$

If the cointegrating relationship is established between $\log \mathrm{GDP}$ and $\log$ of $\mathrm{X}=(\mathrm{GFCF}, \mathrm{LG}, \mathrm{TRA}, \mathrm{M} 2)^{\prime}$, Granger causality test is conducted in the following error correction representation:

$$
\begin{aligned}
& \Delta \operatorname{logGDPt}=\mu_{t}+\delta_{1} \mathrm{ECT} \mathrm{t}-1+\sum_{I=1}^{P} \alpha_{I} \Delta \operatorname{logGDP}_{\mathrm{t}-\mathrm{i}}+\sum_{i=1}^{p} \beta_{i} \Delta X_{t-i}+\varepsilon_{t^{--------}}-(11)
\end{aligned}
$$

where ECT t-1 is the error correction term representing the long-run relationship between logGDP and $\mathrm{X}=G F C F, L G, T R A, M 2$ while $\delta_{1}$ represents the sensitivity of the error correction term showing the speed of adjustment to equilibrium values

\section{Hypothesis}

To test whether long-run relationship exists between economic growth and other variables following hypotheses are stated:

$$
\begin{aligned}
& H_{0:} \alpha=\beta=\gamma_{1}=\gamma_{2}=0 \\
& H_{1:} \alpha \sigma=\beta \sigma=\gamma_{1} \sigma=\gamma_{2} \sigma=0
\end{aligned}
$$

\section{Data Analysis and Results}

The study is based on the set of factors that determine long-run economic growth in Nepal from 19602019. The productivity of factors into the production function is assumed to be captured by total factor productivity, which in turn depends on exogenous factors such as economic policy. The variables are Gross Domestic Product as a proxy for aggregate output, Gross fixed capital formation as a proxy of capital input. In addition, Broad money as a monetary policy variable and exports as a control for openness. Before estimating the model, it is of interest to examine the time-series properties of the data.

\section{Descriptive Statistics}

Table 1: Descriptive Statistics

\begin{tabular}{llllllllllc}
\hline & n & mean & sd & median & min & max & range & skew & Kurtosis & se \\
\hline GDP & 28 & 4.52 & 1.82 & 4.47 & 0.12 & 8.22 & 8.10 & -0.15 & 0.41 & 0.34 \\
GFCF & 28 & 29.60 & 8.73 & 26.65 & 20.25 & 53.90 & 33.66 & 0.99 & 0.20 & 1.65 \\
TRA & 28 & 15.59 & 5.56 & 14.02 & 8.90 & 26.33 & 17.42 & 0.45 & -1.26 & 1.05 \\
M2 & 28 & 62.59 & 23.80 & 54.22 & 32.06 & 109.05 & 76.99 & 0.52 & -1.01 & 4.50 \\
LG & 28 & -0.08 & 0.22 & -0.06 & -0.39 & 0.36 & 0.74 & 0.16 & -1.12 & 0.04 \\
\hline
\end{tabular}

Table 1 shows descriptive statistics of dependent and independent variables taken in the study. The GDP as the first difference variable as a growth variable is averaged at 4.52. The GFCF taken as a percentage of GDP is averaged well below $30 \%$. Trade openness (TRA) is an export variable that is also taken as a percentage of the GDP. This variable has a mean value of 15.59. M2 is averaged at 62.59. LG as labor growth is averaged just below zero. 


\section{Unit Root Test}

Table 2: Result of Augmented Dickey-Fuller (ADF) Unit Root Test

\begin{tabular}{lcccc}
\hline \multirow{2}{*}{ Variables } & \multicolumn{2}{c}{ Level } & \multicolumn{2}{c}{ Difference } \\
\cline { 2 - 5 } & t statistic & Critical Value & t statistic & Critical Value \\
\hline GDP & $-4.452 *$ & -2.93 & -6.4672 & -1.95 \\
GFCF & -1.7271 & -3.5 & -3.8051 & -1.95 \\
LG & -0.864 & -2.93 & -3.7803 & -1.95 \\
M2 & -3.4172 & -3.5 & -2.7988 & -1.95 \\
TRA & -3.107 & -3.5 & -3.1198 & -1.95 \\
\hline
\end{tabular}

Note: [*] The result of the ADF unit root test shows that all the variables except GDP are Non-stationary at a level. However, all variables are stationary at first difference. Source: Author's estimation

Tables 2 and 3 show Augmented Dicky-Fuller test and Kwiatkowski-Phillips-Schmidt-Shin(KPSS) test results of unit roots respectively.

Table 3: Result of Kwiatkowski-Phillips-Schmidt-Shin (KPSS) Unit Root Test

\begin{tabular}{lllll}
\hline \multirow{2}{*}{ Variables } & \multicolumn{2}{c}{ Level } & \multicolumn{2}{c}{ Difference } \\
\cline { 2 - 5 } & \multicolumn{1}{c}{ t statistic } & \multicolumn{1}{c}{ Critical Value } & t statistic & Critical Value \\
\hline GDP & 0.0889 & 0.146 & $0.0547^{* *}$ & 0.146 \\
GFCF & 0.1801 & 0.146 & 0.0699 & 0.146 \\
LG & 0.2492 & 0.146 & $0.1004 * * *$ & 0.146 \\
M2 & 0.0623 & 0.146 & 0.0433 & 0.146 \\
TRA & $1.34 \mathrm{E}-01$ & 0.146 & 0.1837 & 0.146 \\
\hline
\end{tabular}

Note: $* * *$ and $* * *$ indicates significant level at $1 \%, 5 \%$ and $10 \%$.

Note: [*] The KPSS test in Table 2 above shows that the existence of unit root at a level for variables except GDP, M2 and Exports. But, at the first difference of variables except for Exports, variables are stationary.

Source: Author's estimation

\section{Lag Selection}

Before estimating the ARDL model, lag length has to be determined. We use the Vector Autoregressive (VAR) approach to get the maximum lag. Final Prediction Error (FPE) Schwarz Information Criterion (SIC), and Hannan-Quinn Information Criterion (HQIC) criteria show the optimal lag length 1. Table 4 shows the lag value and criteria.

Table 4: Result of VAR Lag Length Criteria

$=================$
$\mathrm{AIC}(\mathrm{n}) \mathrm{HQ}(\mathrm{n}) \mathrm{SC}(\mathrm{n}) \mathrm{FPE}(\mathrm{n})$
-3
-1

Source: Author's Estimation 


\section{Bounds Test for Co-integration}

To establish a long-run relationship or cointegration between economic growth and other control variables, the ARDL bound test is applied. The first level of the bounds test is carried out on the assumption that the variables are integrated of order zero (G.C, 2020). Secondly, the test is carried out on the assumption that the variables are integrated of order 1. The t-statistic is compared with the upper bound and lower bound. The calculated F-statistic is compared with the critical values at various levels of significance as given by Shin \& Pesaran (2001). The results are presented in Table 4. Therefore, the long-run and short-run dynamics of the ARDL model can be estimated.

\section{Bound F-Test for no cointegration}

Table 4: Result of Bounds F-test (Wald) for no Cointegration

\begin{tabular}{|c|c|c|c|}
\hline Variables & Value & P value & Decision \\
\hline $\mathrm{t}(\ln . \mathrm{GDP}, \ln .(\mathrm{TRA}, . \mathrm{LG}, \mathrm{M} 2, \mathrm{GFCF}))$ & 8.216688 & $0.000589^{*}$ & Cointegration \\
\hline $\mathrm{t}(\ln . \mathrm{TRA}, \ln . \mathrm{GDP}, \ln . \mathrm{LG}, \ln . \mathrm{M} 2, \ln . \mathrm{GDP})$ & 7.6815343 & $0.00071 *$ & Cointegration \\
\hline $\mathrm{t}(\ln . \mathrm{M} 2, \ln . \mathrm{TRA}, \ln . \mathrm{LG}, \ln . \mathrm{GDP}, \ln . \mathrm{GDP})$ & 0.57565 & 0.9815 & No-Cointegration \\
\hline t(ln.LG, ln.TRA, ln.GDP, ln.M2 , ln.GDP) & 3.67212865 & $0.08324 * * *$ & Cointegration \\
\hline $\mathrm{t}(\ln . \mathrm{GFCF}, \ln . \mathrm{TRA}, \ln . \mathrm{LG}, \ln . \mathrm{M} 2, \ln . \mathrm{GDP})$ & 1.903141 & 0.57697 & No-Cointegration \\
\hline
\end{tabular}

Source: Author's Estimation

Note: *** and *** indicates significant levels at $1 \%, 5 \%$ and $10 \%$.

Bounds F-test (Wald) for no cointegration

Table 4 shows calculated F-statistics and critical values given by Shin \& Pesaran (2001). The bounds test suggests that two long-run cointegrating relationships exist when $\operatorname{lnGDP}, \ln T R A$, and $\ln L G$ are dependent variables. Hence, the null hypothesis of no cointegration is rejected with $\operatorname{lnM} 2$ and lnGFCF as dependent variables. Since the unit root and bounds test confirm the long-run cointegration relationship, the long-run and short-run dynamics of the ARDL model can be estimated.

\section{ARDL Model}

The estimated long-run coefficients from the ARDL $(1,1,1,1,1)$ model is presented in the following table:

Table 5: Results of the ARDL Model

\begin{tabular}{ll}
\hline & Dependent variable: \\
\cline { 2 - 2 } & In.GDP \\
\hline ln.TRA & 0.192 \\
& $(0.658)$ \\
$\ln . \mathrm{LG}$ & -0.046 \\
& $(0.175)$ \\
$\ln . \mathrm{M} 2$ & $-1.936^{* *}$ \\
& $(0.857)$ \\
$\ln . \mathrm{GFCF}$ & $3.136^{* *}$ \\
& $(1.173)$ \\
Constant & -1.905 \\
& $(4.305)$ \\
\hline
\end{tabular}




\begin{tabular}{ll}
\hline & Dependent variable: \\
\cline { 2 - 2 } & ln.GDP \\
\hline Observations & 28 \\
$\mathrm{R}^{2}$ & 0.276 \\
Adjusted $\mathrm{R}^{2}$ & 0.150 \\
Residual Std. Error & $0.762(\mathrm{df}=23)$ \\
F Statistic & $2.187(\mathrm{df}=4 ; 23)$ \\
\hline
\end{tabular}

Note: $* * *$ and $* * *$ indicate significant level at $1 \%, 5 \%$ and $10 \%$.

Source: Author's Estimation

The long run equation of the ARDL $(1,1,1,1,1)$ model can be presented as follows:

$\operatorname{lnGDPt}=-1.905+3.316 \ln . \mathrm{GFCFt}+-0.046 \ln \cdot \mathrm{LG}_{\mathrm{t}}+0.192 \ln . \mathrm{TRA}_{\mathrm{t}}-1.936 \ln \cdot \mathrm{M} 2$.

Table 5 above suggests GFCF and M2 are significant at a 5\% level. The long-run elasticity is 3.3136 for GFCF. Thus $1 \%$ increase in the GFCF will contribute to a $3.316 \%$ increase in economic growth. Similarly, labor growth impact on economic growth shows a mere negative influence of $4.6 \%$ for every $1 \%$ increase in labor growth similar positive significant results of GFCF to economic growth.

\section{6-4 Error Correction Model}

The purpose of the error correction model is to indicate the speed of adjustment from the short-run equilibrium to the long-run equilibrium state. A Vector Error Correction Model (VECM) is a restricted VAR designed for use with nonstationary series that are known to be cointegrated. Once the equilibrium conditions are attained explained variables in equation II are tested through Perason Johansen technique (Johansen,1988; Johansen,1991; Johansen \& Juselius, 1990) and the results are reported in Table 6.

A natural progression from a VAR representation is the VECM model, especially when the level series are non-stationary. Engle and Granger 1987 showed that any cointegrated series has an error correction specification. Table 6 shows the summary results of the error correction model for Nepal.

Table 6: Error Correction Model

\begin{tabular}{lcccc}
\hline & Estimate & Std. Error & t-value & P value \\
\hline $\mathrm{d}(\ln . \mathrm{TRA}$ & 2.6647 & 0.939 & 2.838 & $0.009574 * *$ \\
$\mathrm{~d}(\ln . \mathrm{LG})$ & -0.1711 & 0.1603 & -1.068 & 0.297217 \\
$\mathrm{~d}(\ln . \mathrm{M} 2)$ & 0.9869 & 1.6384 & 0.602 & -0.01 \\
$\mathrm{~d}(\ln . \mathrm{GFCF})$ & 4.3385 & 1.0549 & 4.113 & $-0.54 * * *$ \\
ect & -1.2578 & 0.1693 & -7.429 & $0.197 \mathrm{e}-07 * * *$ \\
\hline
\end{tabular}

The equation estimated of the error correction model of the ARDL is given as follows:

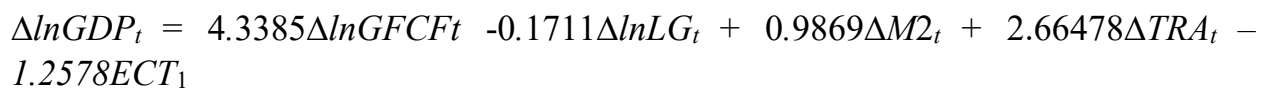

The estimated coefficient of error-correction term ect1 in the equation is -1.2578. The negative value confirms the existence of long-run relationships among the variables and also shows that the disequilibrium from the shock of the previous year converges back to the long-run equilibrium at the speed of $12.5 \%$ per annum. The short-run elasticity of GFCF is $43.85 \%$ and labor growth (LG) is negative at $17.11 \%$. 


\section{Parameter Stability}

\section{Recursive CUSUM test}

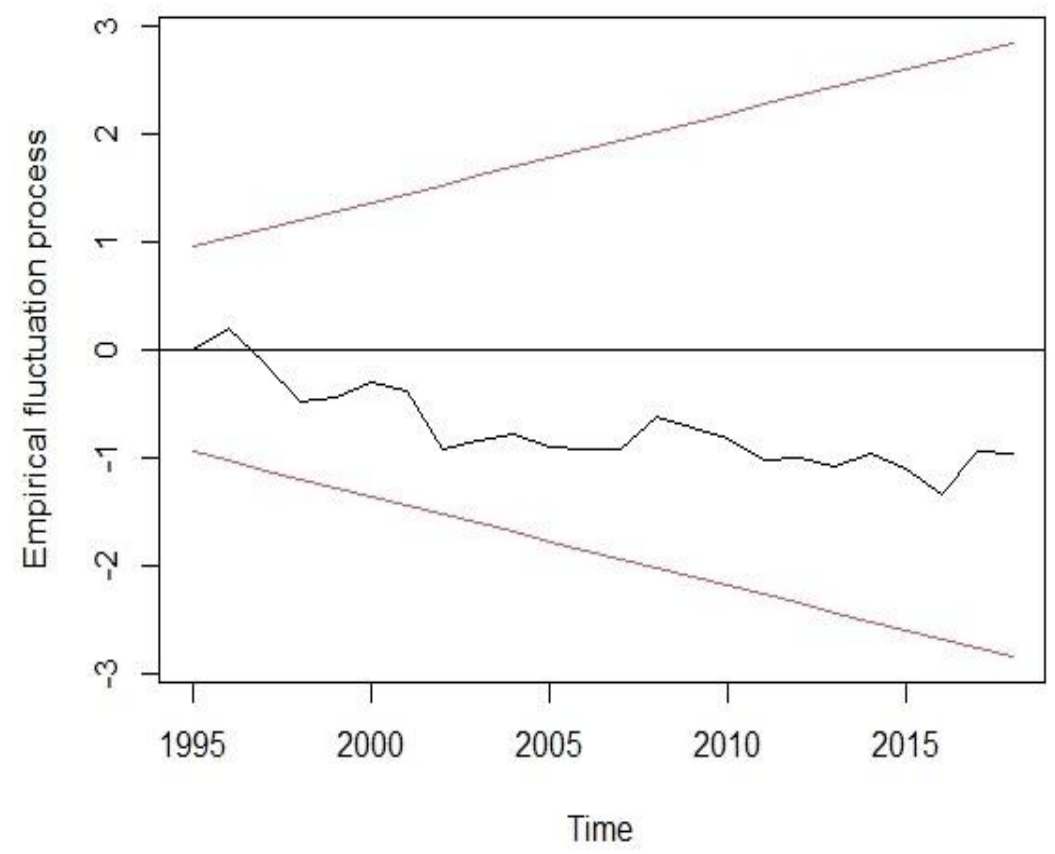

The plots of the CUSUM statistics are well within the critical bounds, implying that, all coefficients in the ECM model are stable over the sample period 1991-2018.

\section{Conclusion}

The paper was an attempt to find the long-run relationship between macroeconomic policy variables and economic growth. The variables taken as the measure of the economic indicator are widely accepted. The ARDL test result produced the presence of cointegration among variables of the study: GDP, GFCF, Broad Money(M2), Exports (TRA) and Labor. The lag length is estimated at 1 for all variables. The bound test of F-statistics indicated the presence of a long-run relationship among variables with ln.GDP as a dependent variable. ARDL $(1,1,1,1,1)$ is estimated. The short-run relationship with error correction term is estimated at $12.5 \%$.

The limited size of the data-set limited the scope of the study wherein lack of correlation among the few economic indicators makes the subject matter analysis more relevant. With more data-set employed into the analysis and equally better indicators in the measure of economic policy, the study can show better and much clearer insights into the interdependence of the variables. The policymaker thus can make a well-informed decision based on such results.

\section{References}

Budha, Birendra. (2012). A multivariate analysis of savings, investment and growth in Nepal.

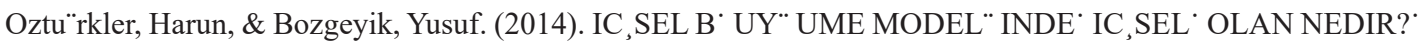
Dicle Universitesi" Iktisadi ve· Idari Bilimler Faku"ltesi Dergisi, 4, 30-37. http://www.dicle.edu.tr/iibfdergisi. ISSN: 1309-4602.

Dervis, Kemal, \& Petri, Peter A. (1987). The macroeconomics of successful development: What are the lessons? NBER Macroeconomics Annual 2:211-254. 
Easterly, William, \& Sergio Rebelo. (1993). Fiscal policy and economic growth. Journal of Monetary Economics, $32(3), 417-458$.

Engle, Robert F, \& Granger, Clive WJ. (1987).

Faux, Elkanah E. (2019). Long-run growth and economic policy in Cameroon: A cointegration analysis." Journal of Economics and Development Studies. IES 7 (4). doi:10.15640/jeds.v7n4a1. https://doi. org/10.156402Fjeds. v7n4a1.

Johansen, Søren. (1988). Statistical analysis of cointegration vectors. Journal of Economic Dynamics and Control, $12(2-3), 231-254$.

Johansen, Soren, and Katarina Juselius. (1990). Maximum likelihood estimation and inference on cointegrationwith applications to the demand for money. Oxford Bulletin of Economics and Statistics, 52 (2), 169-210.

Lucas Jr, Robert E. (1988). On the mechanics of economic development. Journal of Monetary Economics, 22 (1), $3-42$.

Pesaran, M. Hashem, Shin, Y., \& Smith, Richard J. (2001). Bounds testing approaches to the analysis of level relationships. Journal of Applied Econometrics, 16.3, 289-326.

Phillips, Peter CB, \& Perron, Pierre. (1988). Testing for a unit root in time series regression. Biometrika, 75 (2), 335-346.

Romer, Paul M. (1986). Increasing returns and long-run growth. Journal of Political Economy, 94 (5), 1002-1037.

Solow, Robert M. (1956). A contribution to the theory of economic growth.The Quarterly Journal of Economics, 70 (1), 65-94.

Swan, Trevor W. (1956). Economic growth and capital accumulation. Economic Record, 32 (2), 334-361.

Zaman, Gheorghe, \& Goschin, Zizi. (2010). Technical change as an exogenous or endogenous factor in the production function models: Empirical evidence from Romania. Journal for Economic Forecasting, 2, $29-45$. 